\title{
Survey of Historical Water Column Profiles for the COPE 95 Experiment
}

Harry F. Robey

PEPEVISD

SEP 091396

OSTI

February 15, 1995

This is an informal report intended primarily for internal or limited external distribution. The opinions and conclusions stated are those of the author and may or may not be those of the Laboratory.

Work performed under the auspices of the U.S. Department of Energy by the

Lawrence Livermore National Laboratory under Contract W-7405-Eng-48. \section{.}




\section{DISCLAIMER}

This docaument was prepared as an acoount of work sponsored by an agency of the United States Government. Neither the United States Government nor the University of California nor any of their employees, makes any warranty, express or implied, or assumes any legal liability or responsibility for the accuracy, completeness, or usefulness of any information, apparatus, product, or process disclosed, or represents that its use would not infringe privately owned rights. Reference herein to any specific commercial product, process, or service by trade name, trademark, manufacturer, or otherwise, does not necessarily constitute or imply its endorsement, recommendation, or favoring by the United States Government or the University of California. The views and opinions of authors expressed herein do not necessarily state or reflect those of the United States Government or the University of California, and shall not be used for advertising or product endorsement purposes.

This report has been reproduced directly from the best available copy.

Available to DOE and DOE contractors from the Office of Scientific and Technical Information

P.O. Box 62, Oak Ridge, TN 37831

Prices available from (615) 576-8401, FTS 626-8401

Available to the public from the

National Technical Information Service

U.S. Department of Commerce

5285 Port Royal Rd.

Springfield, VA 22161 


\section{DISCLAIMER}

Portions of this document may be illegible in electronic image products. Images are produced from the best available original document. 


\title{
Survey of Historical Water Column Profiles
}

for the COPE 95 Experiment

\author{
Harry F. Robey
}

February 15, 1995 
February 15,1995

To : Distribution

From : H. F. Robey

Subject : Survey of historical water column profiles for COPE experiment

A preliminary survey of water column measurements in the vicinity of the COPE experiment has been conducted. Figure 1 shows a map of the region under consideration, near the mouth of the Columbia River along the coast of Oregon. The historical data comes from a set of two CD-ROMs from the National Oceanographic Data Center (NODC) which contain global ocean temperature and salinity profiles taken between 1900 and 1990. Disk 1 contains 1.62 million profiles from the Atlantic, Indian, and Polar oceans. Disk 2 contains 1.57 million profiles from the Pacific ocean.

The data is organized in files containing all-profiles within an area measuring $10^{\circ}$ of latitude by $10^{\circ}$ of longitude. Figure 2 shows the grid system for disk 2 . Within each of these files, the individual profiles are separated by headers containing the latitude and longitude in degrees and minutes, the date and time of the profile measurement to the nearest 10th of an hour, the vessel country of origin and ID number, the number of data points in the file and the type of measurement (CTD, XBT, etc.). An example of the header information is as shown here:

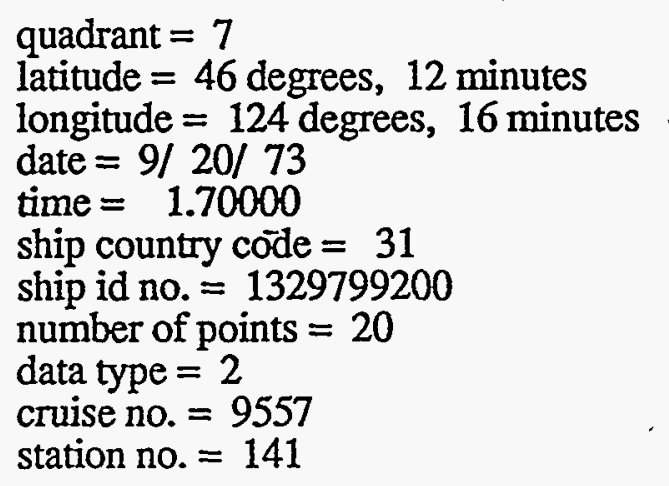

For this report, a survey was conducted for cell number 7412 . The time of year was restricted to the month of September only. Latitude and longitude were restricted for this search to the range from $45^{\circ} 50^{\prime}$ to $46^{\circ} 10^{\prime} \mathrm{N}$ latitude and $124^{\circ} 0^{\prime}$ to $124^{\circ} 30^{\prime} \mathrm{W}$ longitude. This area has a significant overlap with the $30 \mathrm{Km}$ radius covered by the proposed hillside radar. 48 profiles were found meeting these criteria, most of them being rather shallow profiles very close to the mouth of the Columbia River. Of these, 6 profiles from 3 different years have been analyzed for this report. The location of each profile is shown on Figure 1 and listed in the table below as well. For each case, plots are shown of the temperature, salinity, density, and Brunt-Vaisala (BV) frequency. From the BV profiles, dispersion relations are calculated. For each case, plots of the dispersion relation, phase and group velocities and the eigenfunction of the internal wave vertical velocity are shown for the first two internal wave modes. The following table summarizes the important information for each profile. The dates and locations of the measurements are shown followed by the depth of the profile, the peak BV frequency, the depth of the peak, and the long wave phase speed for mode 1 waves, $c_{p}(0)$. 
Profile Summary Table

\begin{tabular}{|c|c|c|c|r|c|c|c|}
\hline Profile & Date & Lat. & Long. & $\begin{array}{c}\text { Depth } \\
(\mathrm{m})\end{array}$ & $\begin{array}{c}\mathrm{BV}_{\max } \\
(\mathrm{rad} / \mathrm{s})\end{array}$ & $\begin{array}{c}\mathrm{D}_{\max } \\
(\mathrm{m})\end{array}$ & $\begin{array}{c}\mathrm{c}_{\mathrm{p}}(0) \\
(\mathrm{cm} / \mathrm{s})\end{array}$ \\
\hline 1 & $9 / 26 / 72$ & $45^{\circ} 49^{\prime}$ & $124^{\circ} 22^{\prime} \cdot$ & 140 & 0.053 & 14.0 & 49 \\
2 & $9 / 26 / 72$ & $45^{\circ} 50^{\prime}$ & $124^{\circ} 9^{\prime}$ & 90 & 0.046 & 11.0 & 43 \\
3 & $9 / 20 / 73$ & $46^{\circ} 11^{\prime}$ & $124^{\circ} 29^{\prime}$ & 120 & 0.047 & 27.0 & 63 \\
4 & $9 / 20 / 73$ & $46^{\circ} 12^{\prime}$ & $124^{\circ} 16^{\prime}$ & 80 & 0.070 & 11.0 & 44 \\
5 & $9 / 18 / 78$ & $46^{\circ} 0^{\prime}$ & $124^{\circ} 20^{\prime}$ & 120 & 0.085 & 7.5 & 75 \\
6 & $9 / 18 / 78$ & $46^{\circ} 0^{\prime}$ & $124^{\circ} 12^{\prime}$ & 90 & 0.112 & 5.0 & 65 \\
\hline
\end{tabular}

The profiles are all basically similar, with a relatively near-surface peak in the BV profile between 5 and 27 meters depth. The maximum BV frequency ranges from 0.046 to 0.112 radians/s. The corresponding dispersion relations give long-wave phase speeds in the range of $43 \mathrm{~cm} / \mathrm{s}$ to $75 \mathrm{~cm} / \mathrm{s}$. Phase and group velocities for higher wave number internal waves have a smaller variation from profile to profile.

These profiles should be characteristic of the type of profiles to be expected during the COPE experiment. 


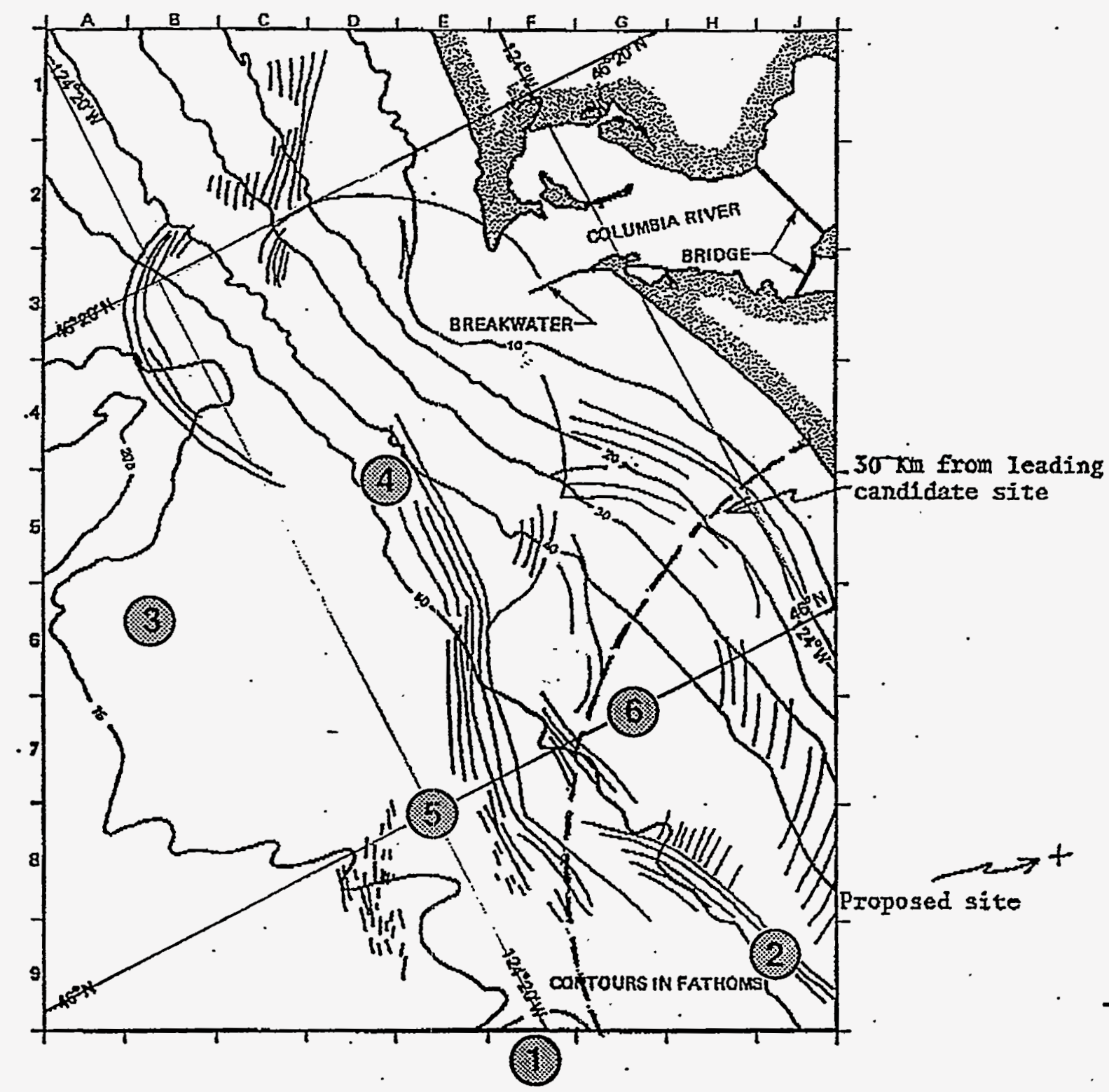

Figure 1. Map of the region with location of profiles 
Appendix B. WMO Ten-Degree Squares for the Pacific Ocean

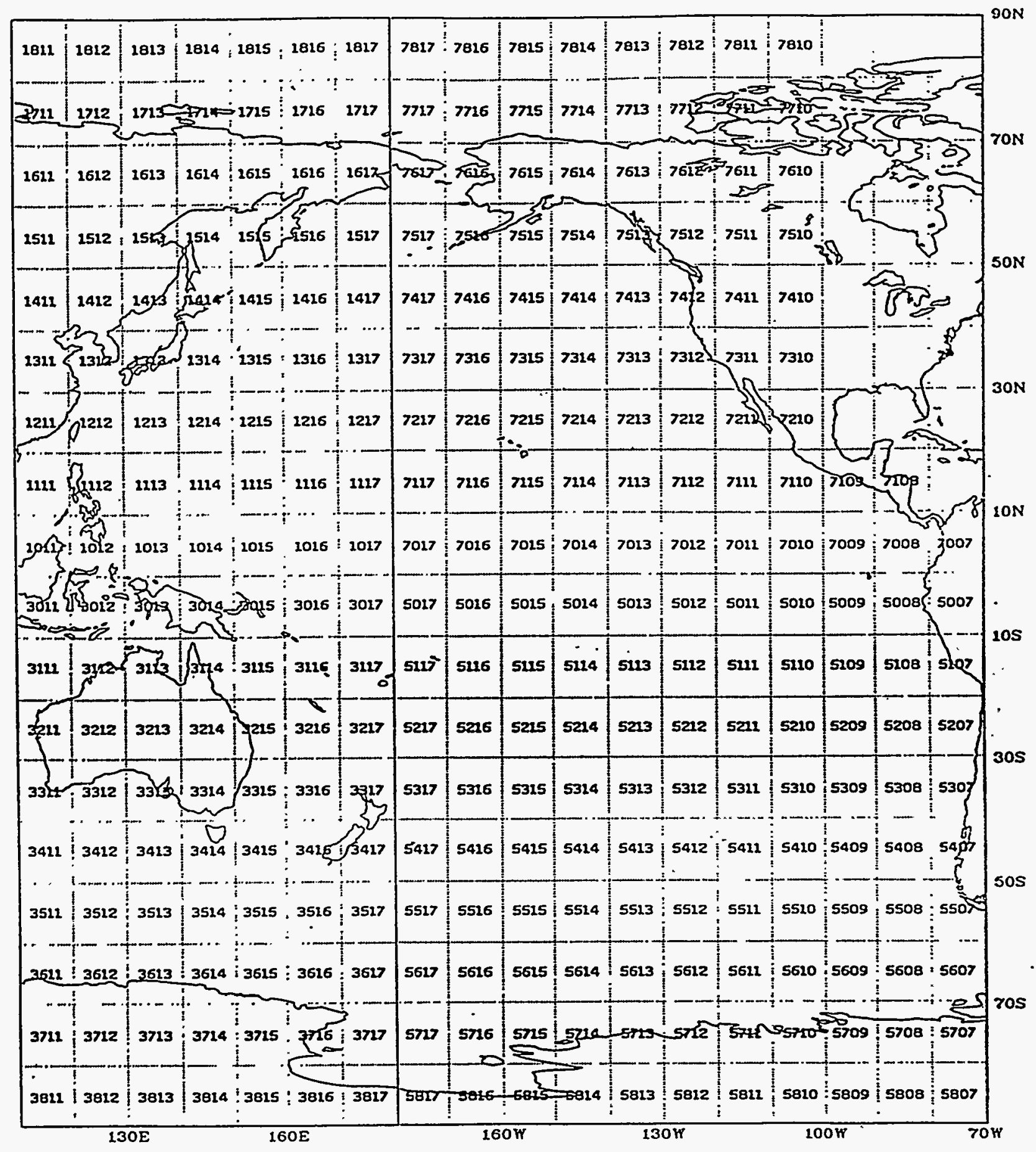

Figure 2. Grid system for NODC data set 

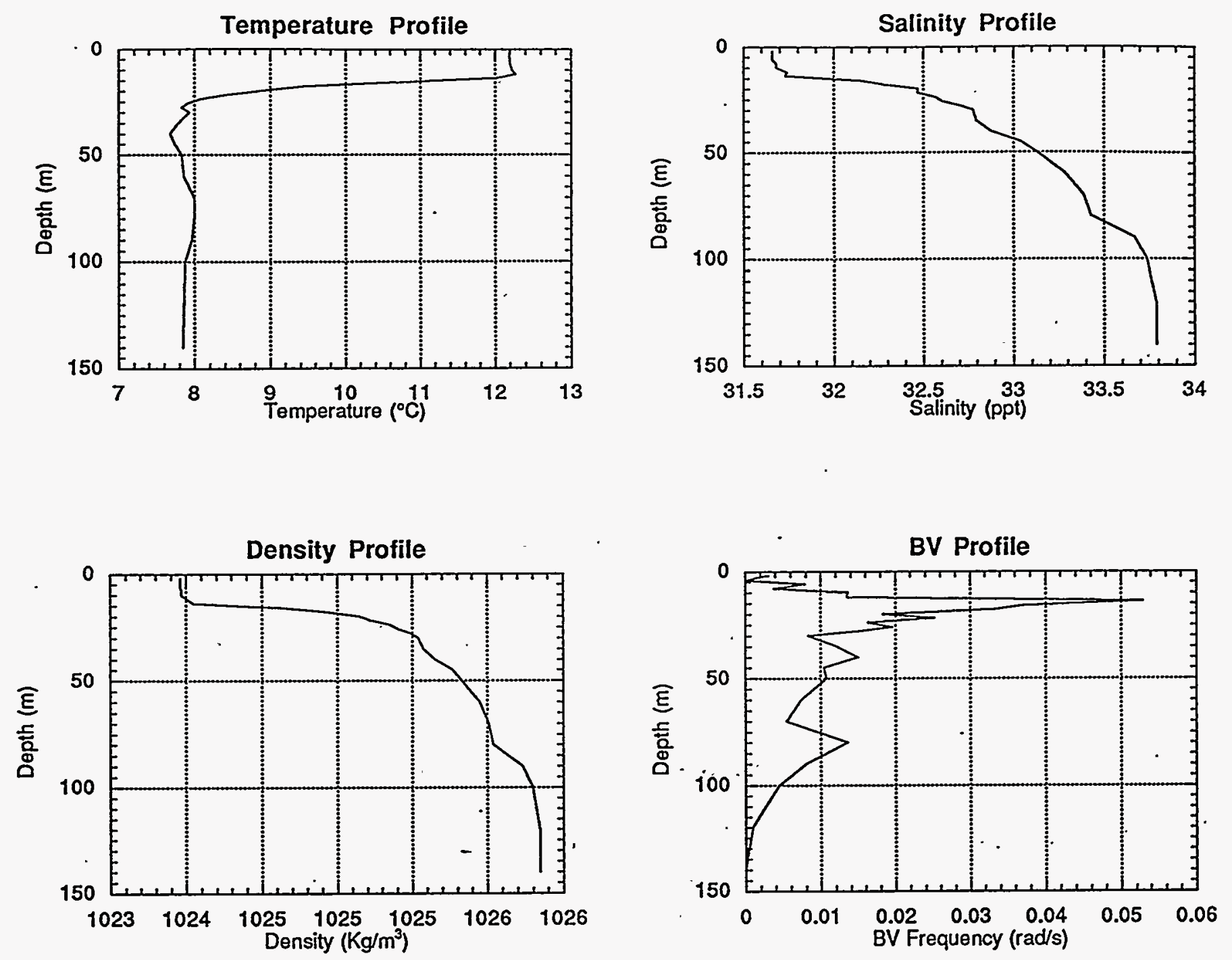

Profile Parameters :

Date : $\quad 9 / 26 / 72$

Latitude : $\quad 45^{\circ} 49^{\circ}$

Longitude : $124^{\circ} 22^{\circ}$ 

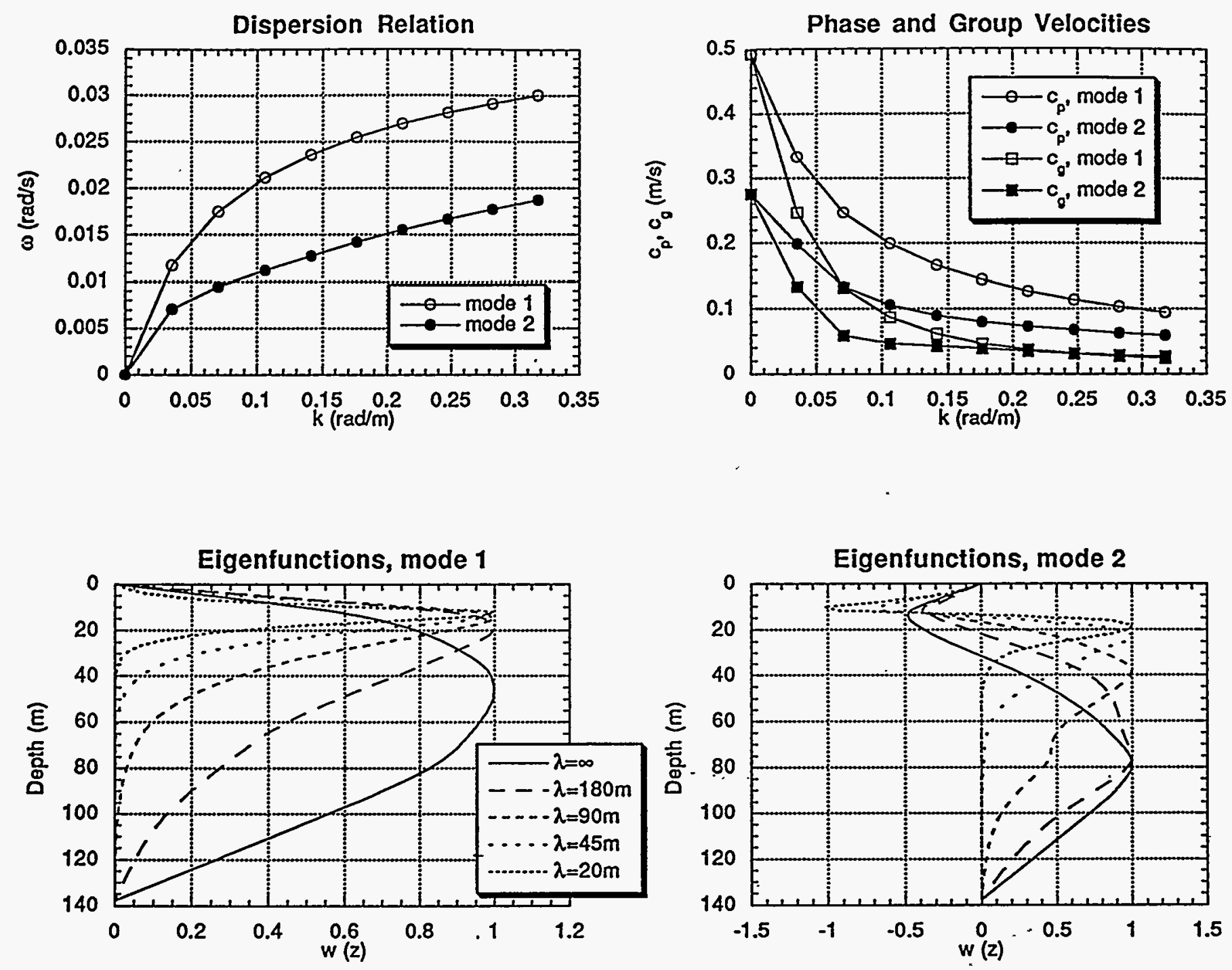

Profile Parameters :

Date : $\quad 9 / 26 / 72$

Latitude : $\quad 45^{\circ} 49^{\circ}$

Longitude : $124^{\circ} 22^{\prime}$ 

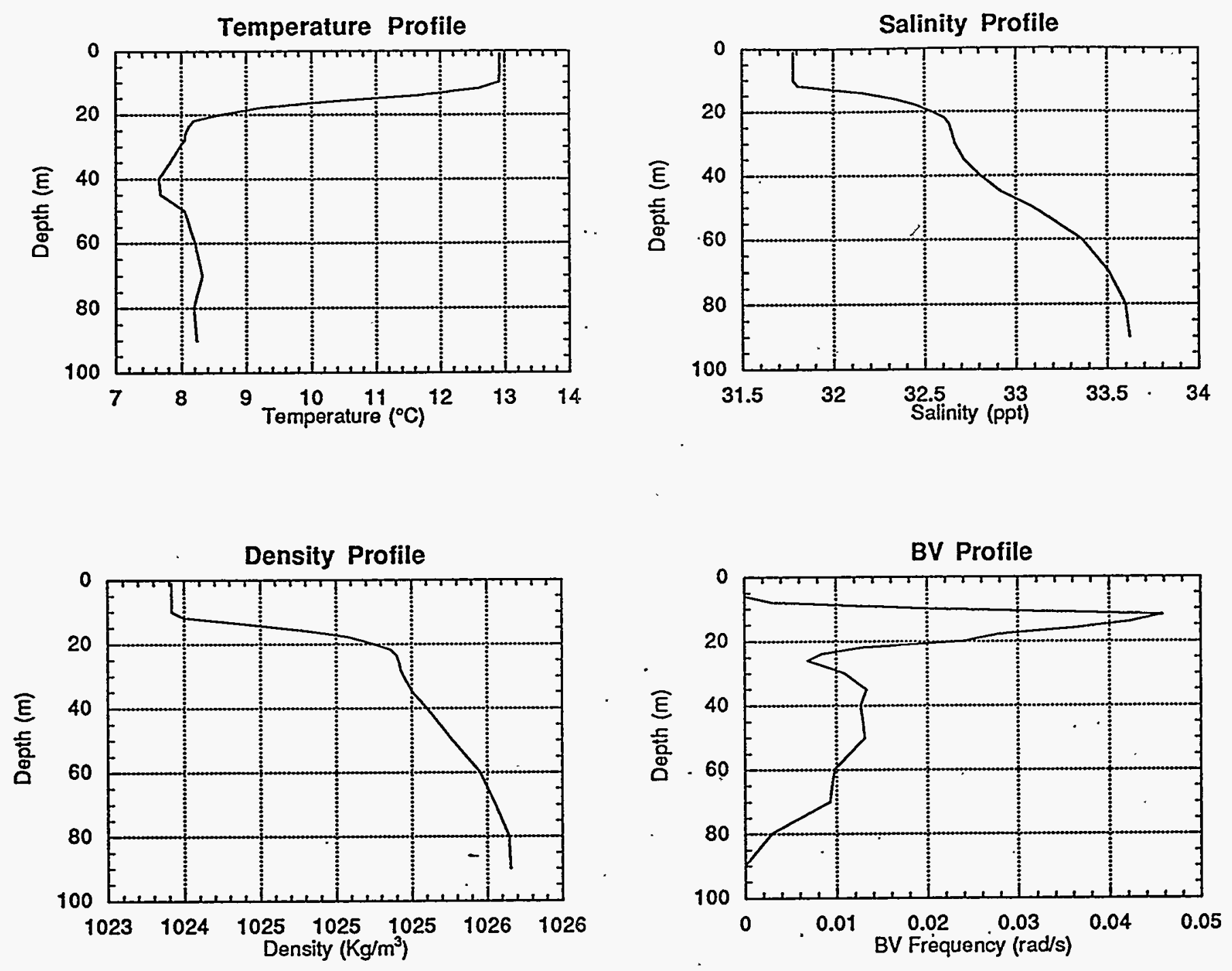

Profile Parameters :

Date : $\quad 9 / 26 / 72$

Latitude : $\quad 45^{\circ} 50^{\circ}$

Longitude : $124^{\circ} 9^{\circ}$ 

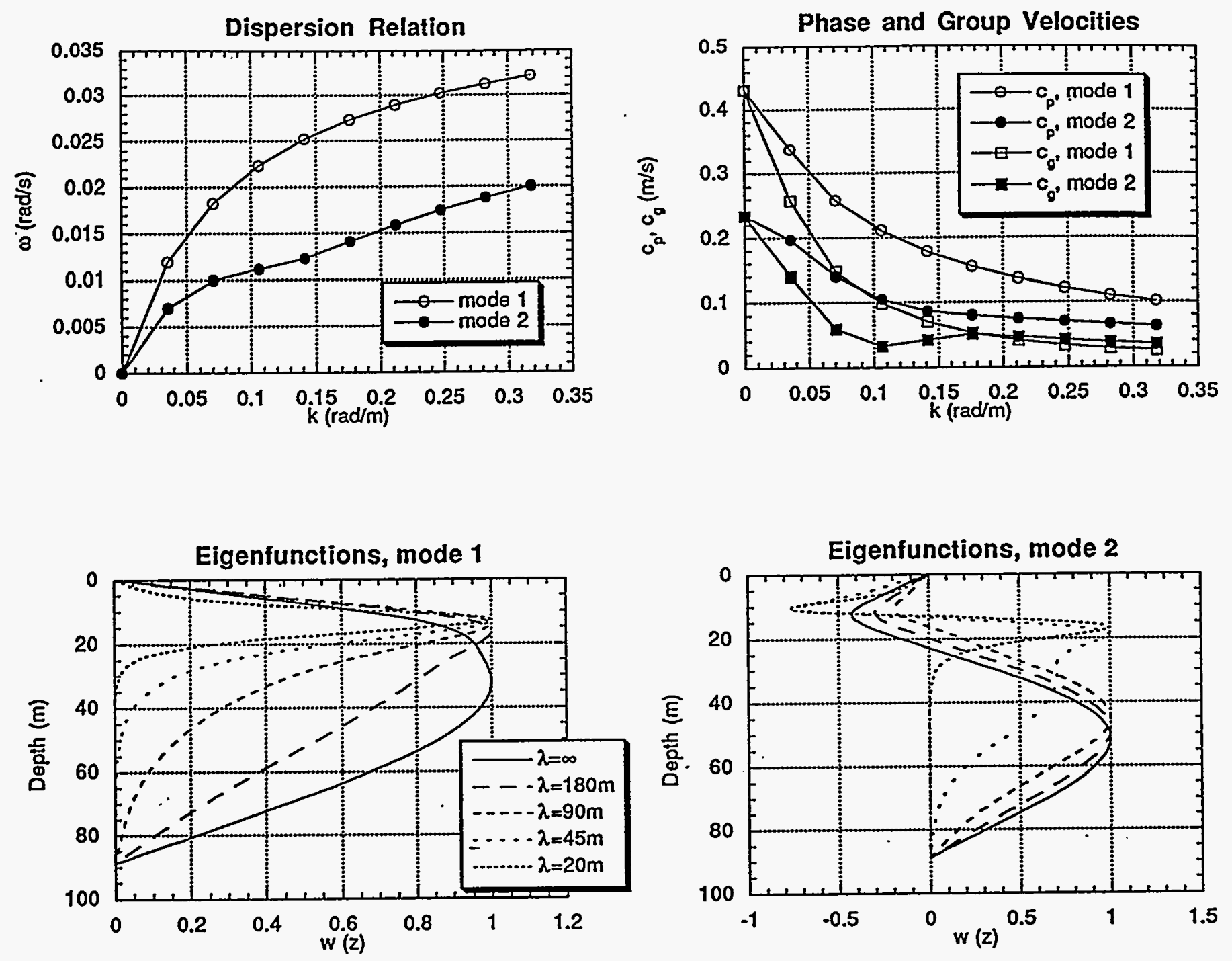

Profile Parameters :

Date : $\quad 9 / 26 / 72$

Latitude : $\quad 45^{\circ} 50^{\circ}$

Longitude : $124^{\circ} 9^{\prime}$ 

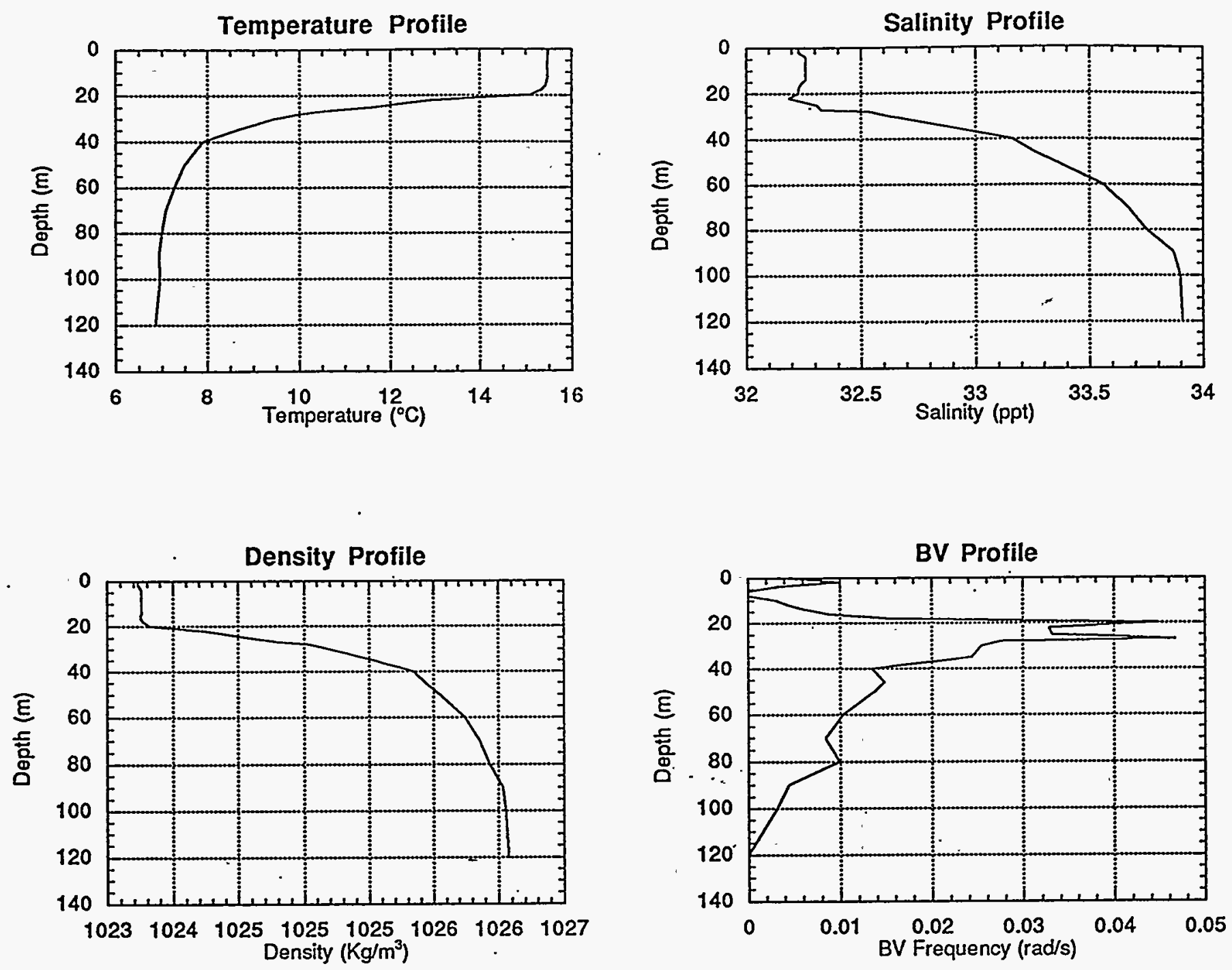

Profile Parameters :

Date : $\quad 9 / 20 / 73$

Latitude : $\quad 46^{\circ} 11^{\prime}$

Longitude : $124^{\circ} 29^{\circ}$ 

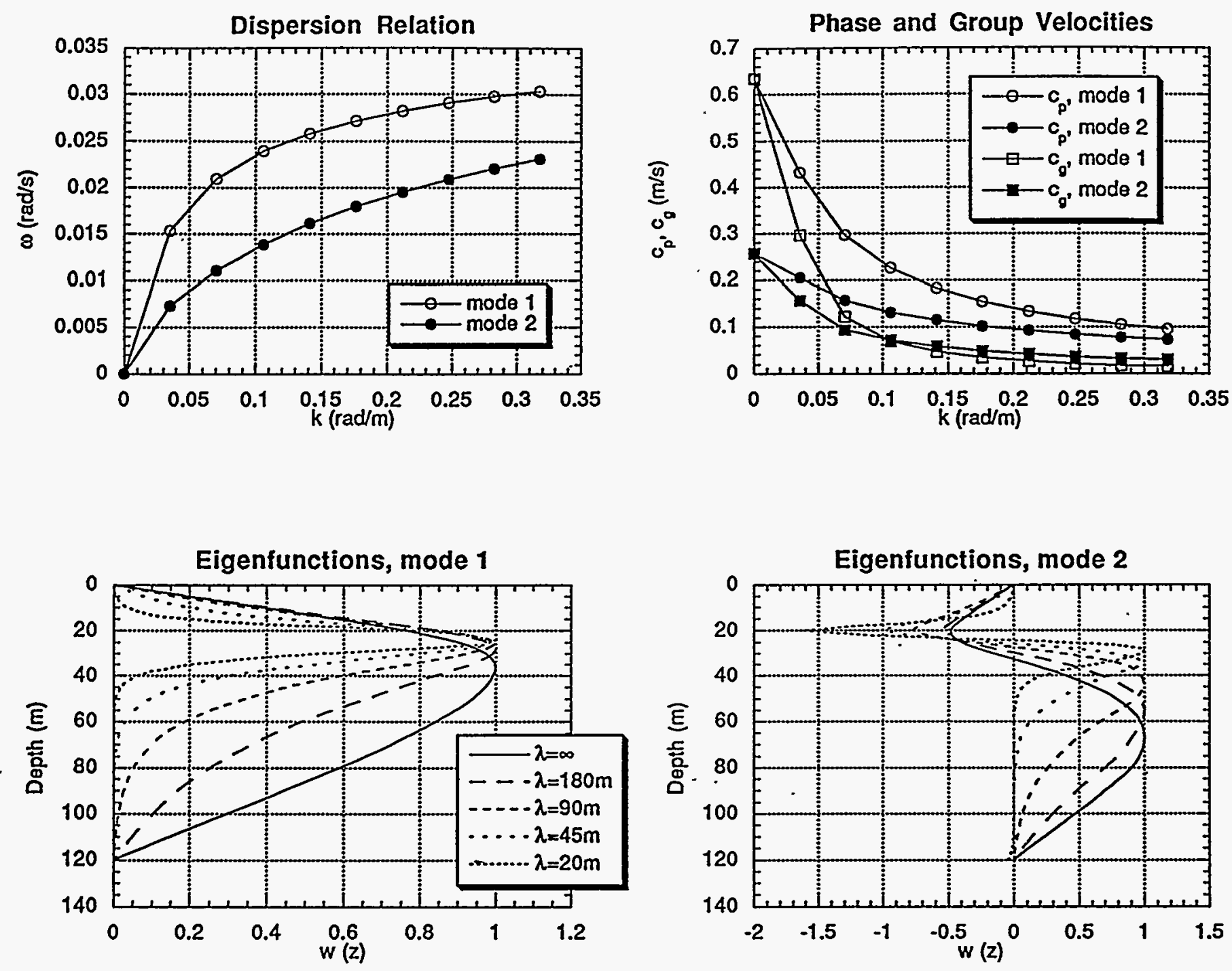

Profile Parameters :

Date : $\quad 9 / 20 / 73$

Latitude : $\quad 46^{\circ} 11^{\circ}$

Longitude : $124^{\circ} 29^{\circ}$ 
Temperature Profile
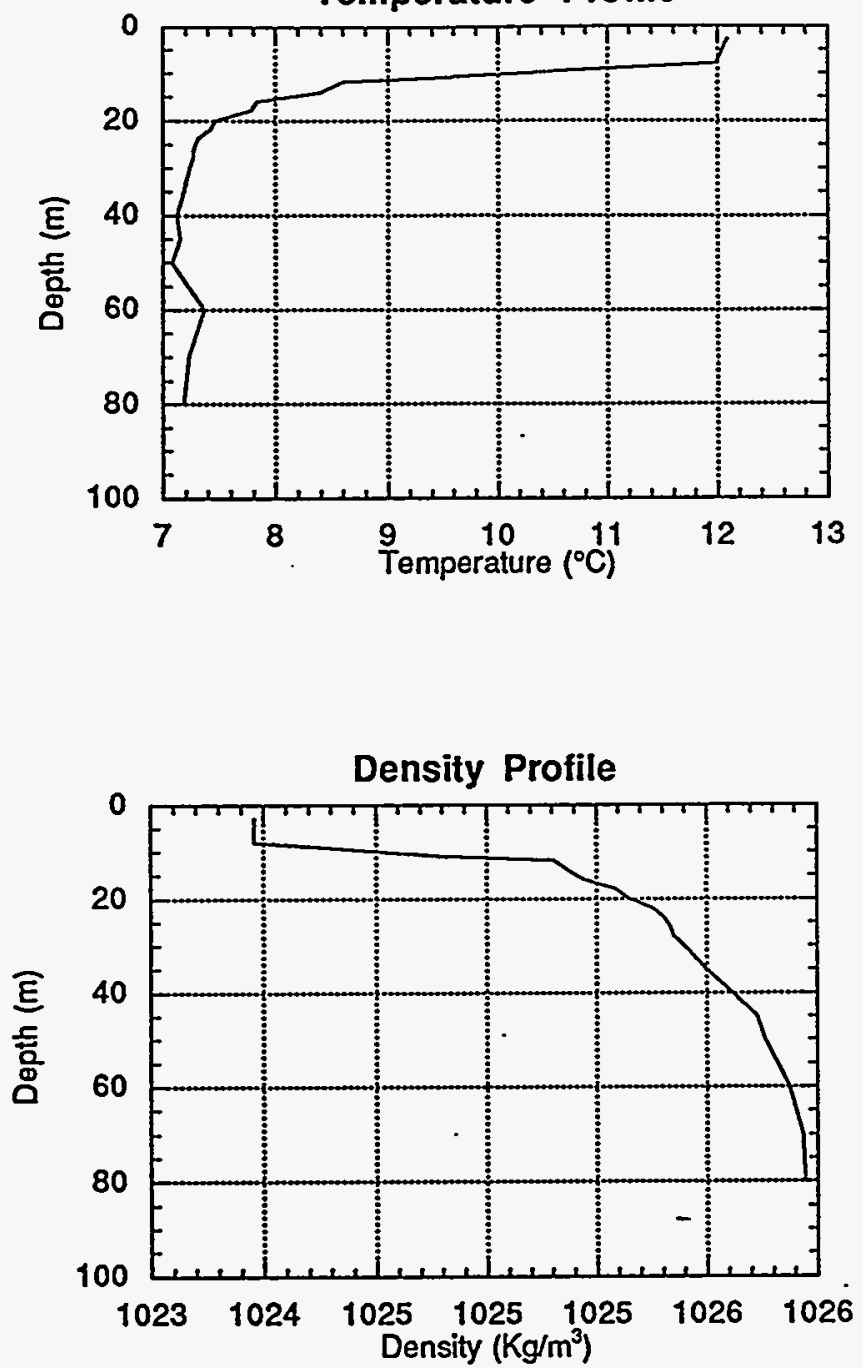

Salinity Profile

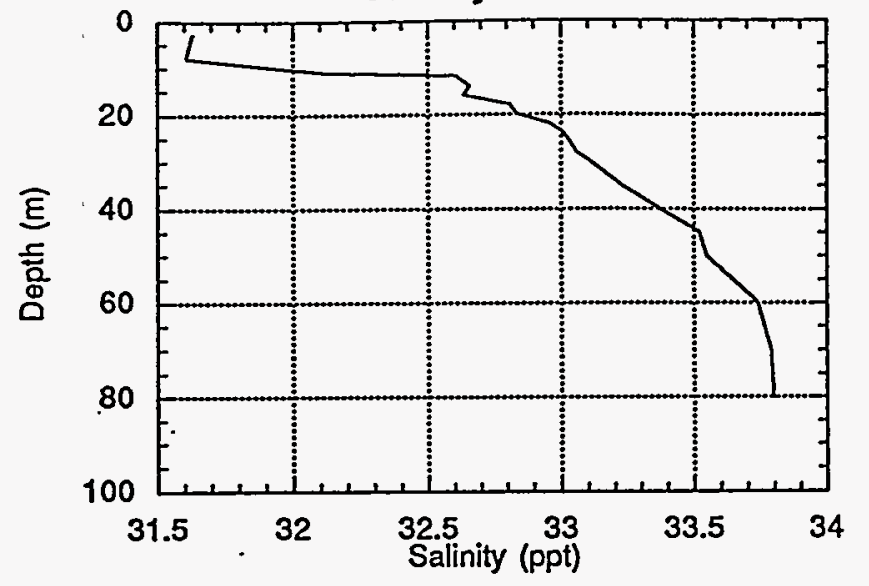

\section{BV Profile}

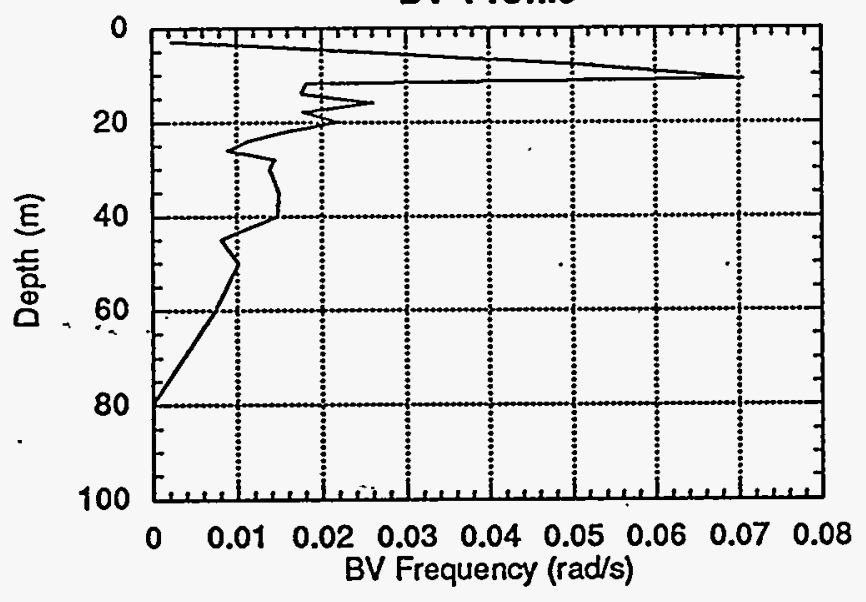

Profile Parameters :

Date : $\quad 9 / 20 / 73$

Latitude : $\quad 46^{\circ} 12^{\prime}$

Longitude : $124^{\circ} 16^{\prime}$ 

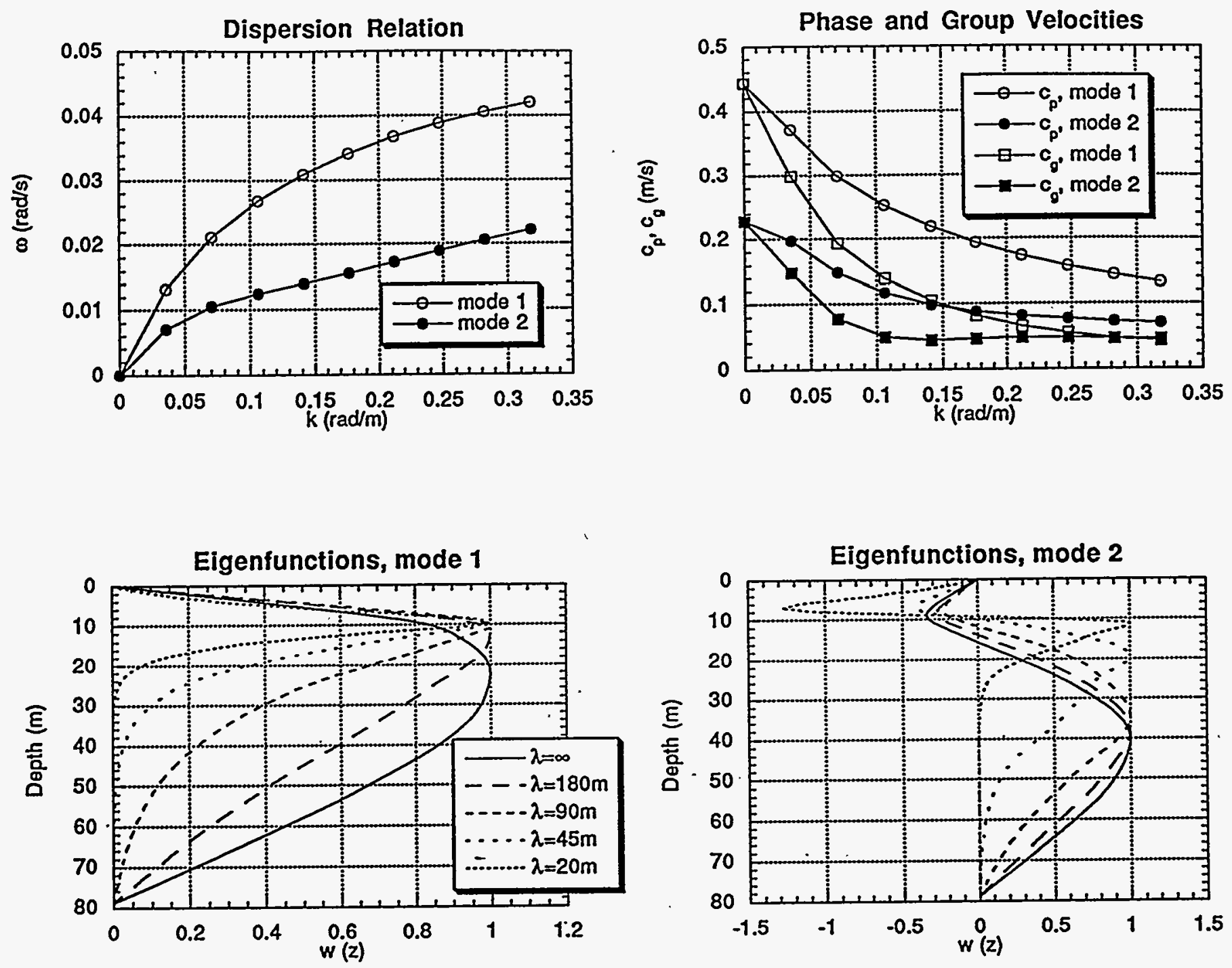

Profile Parameters :

Date : $\quad 9 / 20 / 73$

Latitude : $\quad 46^{\circ} 12^{\prime}$

Longitude : $124^{\circ} 16^{\prime}$ 

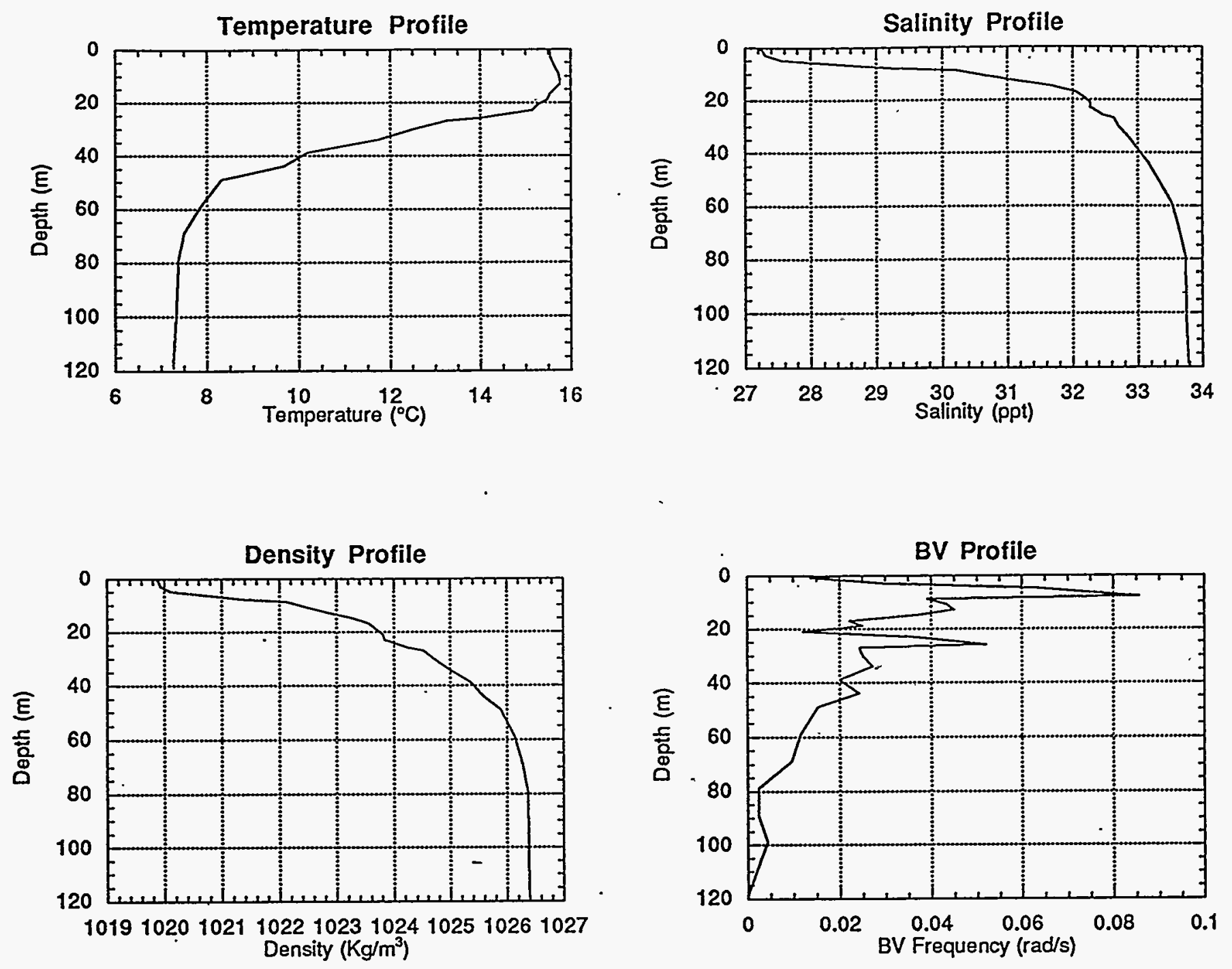

Profile Parameters :

Date : $\quad 9 / 18 / 78$

Latitude : $\quad 46^{\circ} 0^{\prime}$

Longitude : $124^{\circ} 0^{\circ}$ 

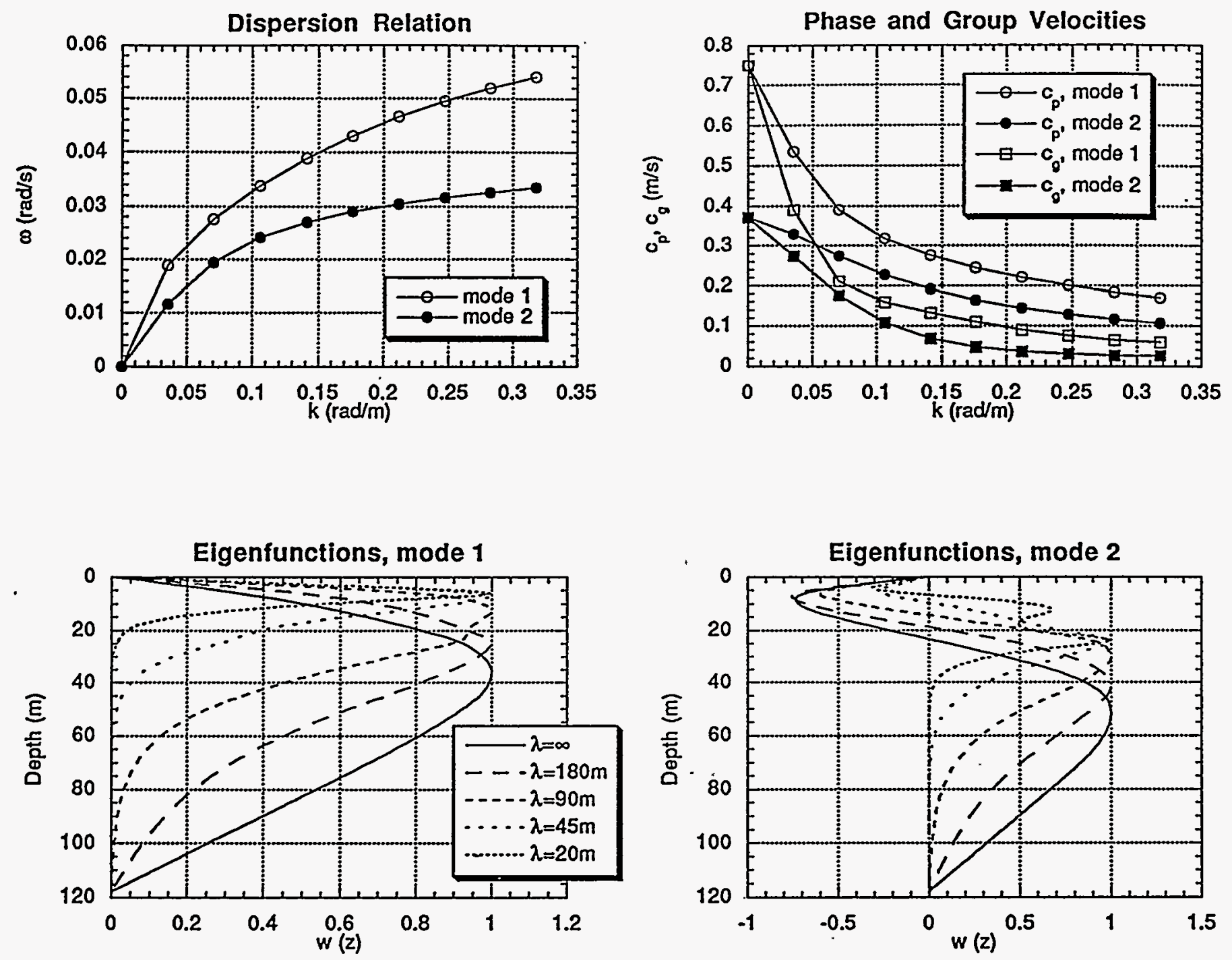

Profile Parameters :

Date : $\quad 9 / 18 / 78$

Latitude : $\quad 46^{\circ} 0^{\prime}$

Longitude : $124^{\circ} 0^{\circ}$ 

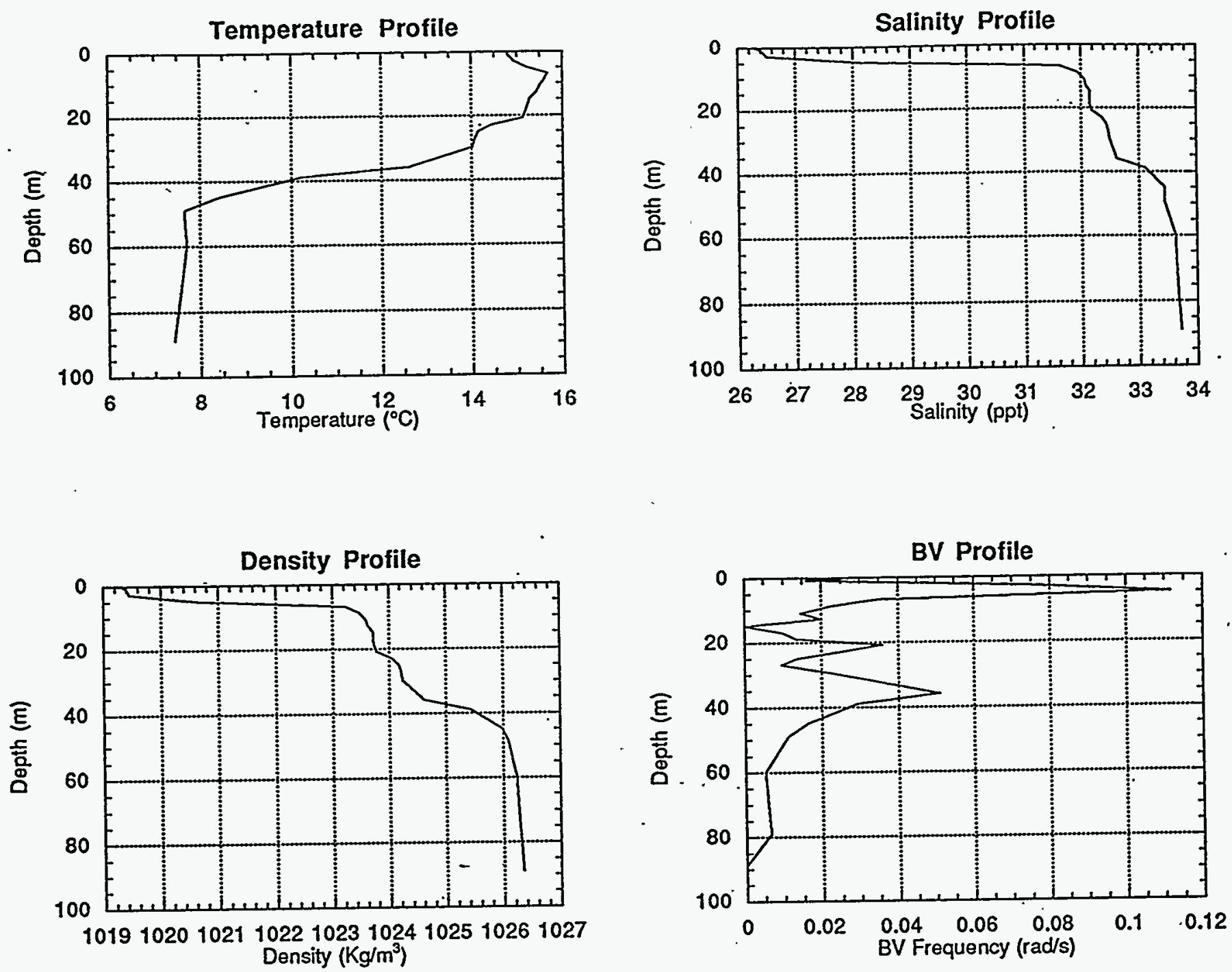

Profile Parameters :

Date : $\quad 9 / 18 / 78$

Latitude : $\quad 46^{\circ} 0^{\prime}$

Longitude : $124^{\circ} 12^{\prime}$ 

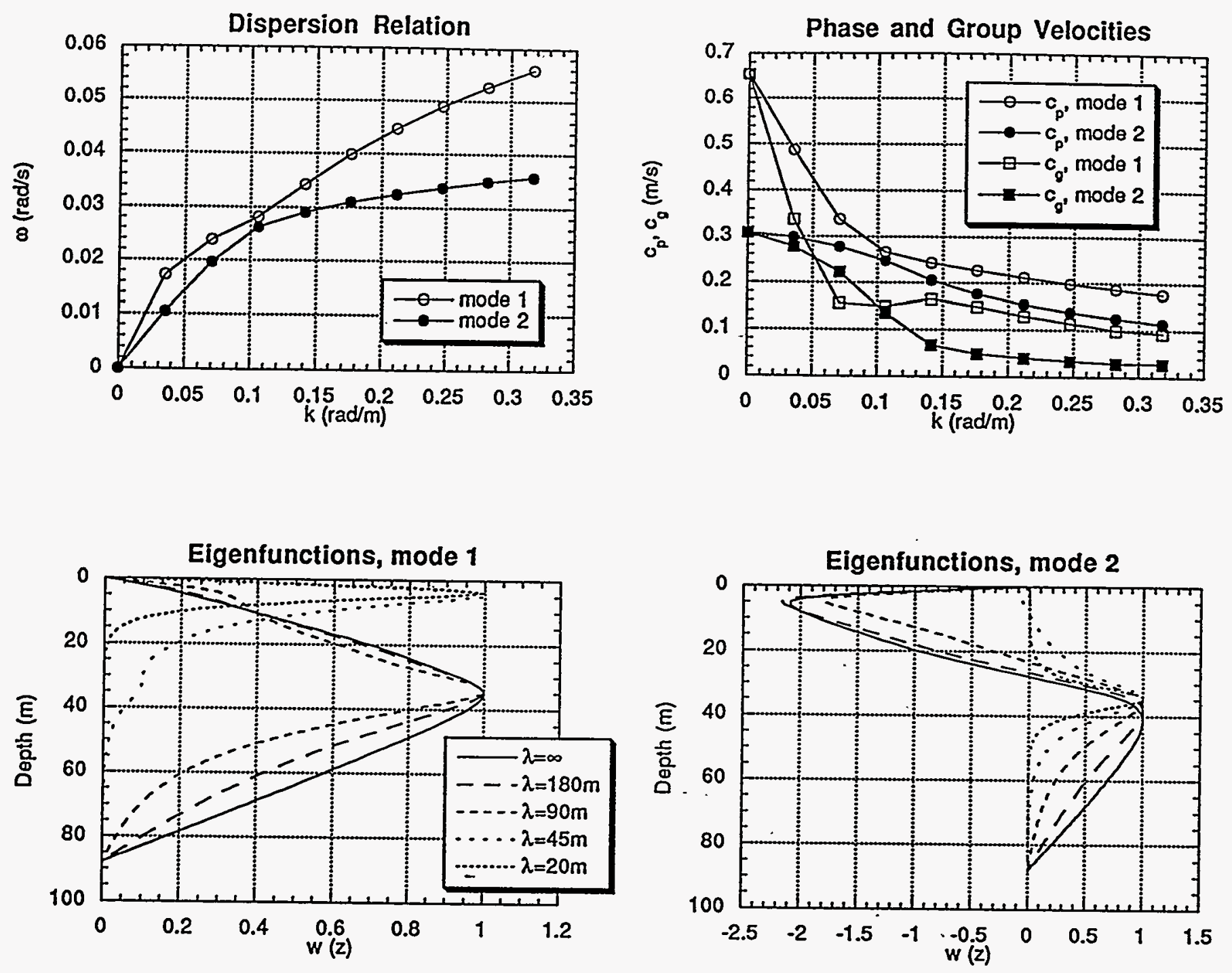

Profile Parameters :

Date : $\quad 9 / 18 / 78$

Latitude : $\quad 46^{\circ} 0^{\prime}$

Longitude : $124^{\circ} 12^{\prime}$ 